\title{
Popular Ideology and Public Policy in Europe: Trends and Popular Ideology as a Determinant of Public Policies?
}

\author{
Peter Kotzian \\ University of Düsseldorf, Düsseldorf, Germany \\ Email: Peter.Kotzian@hhu.de
}

Received 2 March 2016; accepted 24 April 2016; published 27 April 2016

Copyright (C 2016 by author and Scientific Research Publishing Inc.

This work is licensed under the Creative Commons Attribution International License (CC BY).

http://creativecommons.org/licenses/by/4.0/

(c) (i) Open Access

\begin{abstract}
Does popular ideology affect public policies enacted in a country? The baseline argument links popular ideology input to policy output. Either a population more often elects a party with its favored ideology into office, which then implements policies in line with popular ideology. Alternatively, all parties pursue policies more in line with popular ideology. Under the first view, popular ideology should affect government composition, which then matters for policy. Under the second view, policies should track popular ideology, but there should not be an effect of government ideology. If governments were perfect agents, a shift in popular ideology would translate in policy. This is not the case. This leaves two explanations: either that all governments purse the same policies in response to the same problems, or that governments do not actually care about their principals' ideological demands. Comparing, which policies track popular ideology and which are independent of it, indicates that governments follow popular ideology in policies, where they have no bureaucratic self-interest in certain policy developments, but otherwise pursue their own agenda.
\end{abstract}

\section{Keywords}

Public Policy, Government Composition, Comparative Politics, Elections, Popular Ideology

\section{Introduction}

Does popular ideology affect public policies? Do governments follow the ideological demands of their electorate and do they respond if ideological shifts at the individual level? Or are all societies and governments subjected to the same global trends, confronted with the same necessities, and had to respond to them in more or 
less the same way?

Ideology is assumed to be relevant for guiding specific policy decisions (Hinich \& Munger, 1994), in particular the state-economy-relationship, the role of the government in regulating the relations among individuals, firms and the state. For instance, a more leftist ideology implies a favor for state intervention, redistribution, "bigger government", and policies which are more in line with the preferences of workers, for instance regarding employment protection. Liberal/right ideology holds the opposite positions. Even if confronted with the same problems, the policy responses derived from different ideologies are different. As a case in point, when faced with the financial crisis of 2008, different ideological leanings offered different ways out, and in practice, some governments engaged in stimulus-programs, others in austerity.

The underlying the link between citizens' ideology and public policy is that individual-level ideology can be aggregated into popular ideology, it also expresses itself by voting in elections, by which citizens', or rather: voter's ideology is formally aggregated and translated in the partisan composition of government. Then governments of a certain ideological leaning introduce certain policies, e.g. more redistribution and more government intervention in the market in the case of left governments (Downs, 1957). So, ideology of citizens should matter for policies, if the political transmission belt of party competition and elections works as assumed. Different ideologies on the input side will be transposed into different policy outputs, maybe even political outcomes. Shifts in the ideology of citizens should precede shifts in public policy of elected governments. However, the transmission belt concept of electoral politics consists of several links along a chain, each of which can be questioned: does ideology matter for individual voting behavior, and, equivalent for the macro level, does voter ideology matter for the partisan composition of governments? Do governments of a different ideological leaning actually differ in their policies? The paper's research question is, whether popular ideology does indeed affect public policies.

The assumption that public policy tracks citizens' preferences is among the core tenets of electoral studies. Still, an empirical analysis of the relationship between individual-level ideology and policy-developments is of interest, because there are competing arguments, which do not rely on the input of the citizens to explain policy-developments.

First, the globalized economy and general trends prohibit governments to follow markedly individual paths: as the problems are the same, the solutions will have to be more or less identical.

Second, based on delegation theory and bureaucratic theory, one can also argue that governments, regardless of the popular ideology prevailing in the country, prefer and tend to extend the size and scope of government. The mechanism underlying this trend is the institutional interest of the government as an agent, but in particular the interest of the public administration below the ranks of the elected government, in an ever growing public sector (Niskanen, 1971).

The paper is organized as follows: section 2 will very briefly sketch existing findings on the relationship between popular ideology and policy, tracking the electoral link connecting citizens and policy. Section 3 will elaborate potential the causal mechanisms underlying each of the arguments enumerated above. From these causal narratives, we will derive predictions about correlations among indicators of popular ideology, government composition and government activity which might be expected if a certain mechanism is actually at work. Based on survey data combined with data on governmental activities of European countries from 1969 till 1999, section 4 will test the predictions and make an inference about which mechanism is the predominant one, section 5 will conclude.

\section{State of the Art: Popular Ideology and Public Policy}

The relationship between individual-level political attitudes and public policy has several aspects and several causal directions, some of which are studied intensely, others much less so. Dominating is the investigation of the causal flow from the macro-level setting, in particular political and economic conditions, to individual-level political attitudes and behaviors, such as voting behavior (for instance Lewis-Beck, 1985; Lewis-Beck \& Stegmaier, 2000), support for redistribution (Larsen, 2008; Busemeyer et al., 2009; Brunner et al., 2011) or ideological self-placement (Kim \& Fording, 2001). This review of the literature focuses on the main "chain-links" along the transmission-belt view of electoral competition: firstly, individual-level ideology as determinant of voting behavior and thus government composition, secondly, government composition as determinant of public policy, but will also inquire into the state of the art regarding a direct effect of popular ideology on public policy. 


\subsection{Individual-Level Ideology and Voting}

The idea of an underlying ideological space, where the positions of voters and parties determine an individual's voting decision and thereby also policy is clearly the main approach to explaining voting and elections, both at the individual and the macro-level (Downs, 1957; Holm \& Robinson, 1978). This basic approach has from early on competed with the party identification approach and various economic approaches.

The economic approaches use economic factors, in particular government's economic performance, to predict its chances for re-election, basically assuming that voters predominantly care about economics and economic well-being, either their own or that of the country as a whole (Whitten \& Palmer, 1999; Lewis-Beck \& Paldam, 2000; Nadeau et al., 2013). The party identification approach begins with The American Voter (Campbell et al., 1960), and research on voting behavior found strong evidence that party identification, not (only) ideology, is the main explanatory factor in voting behavior, albeit over time, the importance of specific policy issues became more important. These policy-based approaches resulted in refinements, such as the directional voting theory (Rabinowitz \& Macdonald, 1989).

Still, the ideological approach to voting behavior is underlying many theories and empirical approaches to electoral behavior. It assumes ideological proximity between voters and political actors as the main mechanism of voting behavior, explaining for instance also the party affiliation, which gives ideology indirect relevance (Hinich \& Munger, 1994). More recent empirical studies also confirm that ideology is a significant explanatory factor for voting, in established (Listhaug et al., 1994; Jacoby, 2010) as well as emergent democracies (Rudi, 2009). Ideology not only affects voting, but also, how social and political developments are perceived (Rudolph, 2009), and what criteria are relevant for citizens to judge a government's success or failure (Maloney \& Pickering, 2008).

To summarize, while ideology was found to be a significant factor in voting behavior, it is only one among several. Further, voting for parties does not necessarily establish a link between popular ideology and government composition, let alone government policies.

\subsection{Government Composition and Public Policy}

The question, whether government composition is a determinant of policies, and if so, under which conditions and for which policies, is less studied than the link between voters and governments, and the evidence is much less conclusive. Most of the studies focus on the US, fewer cover the European setting. Government ideology is presumed to be relevant for the handling of economic issues (Hibbs, 1977) and found to be relevant for political business cycles and the trade-off between inflation and unemployment (Potrafke, 2012). The strongest evidence of the impact of ideology on policies is found by the study of Poole and Rosenthal on the US Congress, who find that ideology rather than issues-specific aspects, explain most of the voting behavior and thereby most of the policies enacted by Congress (Poole \& Rosenthal, 1997). This finding is partly confirmed by the work of Kau and Rubin who found significant but small effects of ideology on the expansion of taxation after controlling for other, economic, explanatory factors (Kau \& Rubin, 2002).

Regarding the effectiveness of the link between voter ideology and policy, the electoral competition imposes, to some degree, the constraint on the parties to implement the policies the announced during the election campaigns (Klingemann et al., 2006). However, at times there is also the argument for the opposite argument, viz. that parties formulate their political programs and their ideology in a relatively vague and broad way, in order to be attractive for voters from a broad range of ideological leanings. A more specific argument of this type is the territory hypothesis by Maloney and Pickering who argue that parties in a two party system try to cover as much ideological ground as possible, assuming that even voters far away from them will have to vote for them, as the alternative is even further away (Maloney \& Pickering, 2008). Works in the strain of the issue-ownership approach by Budge and Farlie postulate that the electorate assumes parties of different ideological leanings to be competent to tackle different problems, for instance the left is assumed to be better at dealing with unemployment (Budge \& Farlie, 1983). Citizens are presumed to vote for parties depending on the country's most prominent problems (Rattinger, 1991; Swank, 1993). Again, that does not necessarily tell us something about the policies actually enacted. Looking explicitly at the impact of government composition, i.e. the left-right orientation, on government policy, the meta-study by Imbeau et al. who review 43 empirical studies, concludes that there is no difference between left and right governments regarding their policy (Imbeau et al., 2001).

To summarize, there is little evidence that the connection between popular ideology and policy hinges on the composition of governments. 


\subsection{Individual-Level-Ideology and Public Policy}

Regarding the question, whether individual-level opinions and ideologies affect public policy, existing research focuses on certain policies, addressing not the relationship between attitudes and policies but rather between individual attitudes and individual support for certain policies, such as welfare. Here, left-right ideology was found to be relevant in several studies (Jacoby, 1994; George, 1998; Brunner et al., 2011; Jaeger, 2008) for a more detailed investigation into assumed causal direction. However, ideology is only one factor among many, others are personal economic situation and overall economic development. While the relationship presumed most often is that of a causal direction running from citizens to policies, there is also substantial evidence that macro-level events, such as economic developments, or actions by national governments, can and do affect the individual level support for certain policies, in particular welfare policy (Blekesaune \& Quadagno, 2003; Blekesaune, 2007).

At the level of policies actually enacted in a country, early research into public opinion and policy by Wright et al. found for the US that policy does respond to the public opinion in that a more liberal ideology of citizens at state-level implies more liberal policies (Wright et al., 1985; Wright et al., 1987). More recent work, such as Adams et al. found that parties do, to some degree, respond to changes in public opinion, by adapting their programs accordingly, but rather than closely tracking public opinion adapt only, when the divergence is high (Adams et al., 2004).

The transmission of individual-level ideology in the setting of the median voter framework was taken up also in the work by McDonald et al. who measure the degree to which elections actually fulfill their function of transmitting the median voter's position into government composition, finding that the transmission works accurate despite some random fluctuations and some bias due to the electoral system (McDonald et al., 2004). Rudolph and Evans found an intervening effect for ideology on policy (in particular government spending), in that political trust is more relevant for the acceptance of government spending among conservatives, who are willing to accept more government spending only if they have trust in government, than among progressives, who are in favor of government spending regardless of their trust in government (Rudolph \& Evans, 2005). Measuring popular ideology by the reconstructing the median voter's position from party manifestos, Pickering and Rockey find a strong link between government growth and voter ideology in a framework where increasing income increases the demand for public services, to which government reacts by increasing the supply thereof, but this relationship is interdependent with the overall income level, and gets stronger as income increases (Pickering \& Rockey, 2011).

To summarize the review of the literature, there is some evidence for the electoral transmission belt argument, in particular for the US. This paper will inquiry into how popular ideology developed over time in Europe, how strong the links between citizens, governments, and policies are and to what degree popular ideology and changes therein can explain policy developments.

\section{Individual-Level Ideology and Public Policy: Alternative Causal Mechanisms}

The first, implicit, link between ideology and policy is that popular ideology is the aggregate of individual-level ideology: if many citizens move ideologically to the left, popular ideology shifts too. In the following we will use the term popular ideology as referring to the aggregate of all individual ideological positions in the population. While the electoral transmission is the standard view of the link between individual-level ideology and public policy, there are several complications. For instance, it may well be that ideology affects or determines which parties are in government but that parties with different ideological leaning or label do not differ in their policy. It may further be that electoral rules block shifts in popular ideology from being translated into government composition and thus policy shifts. On the other hand, popular ideology in a society may affect public policy even without voting into power a party with a decidedly left of right ideology. All parties may recognize the shift in popular ideology and respond, despite different ideological leanings, in the very same manner. It may also be the case, that policy is neither affected by popular ideology, nor by government ideology. More specifically, there are three ways the relationship between popular ideology and public policy may be seen.

\subsection{Individual Ideology, Elections, and Government Policies}

Individual ideology may affect policy by elections. This implicitly assumes that there are -despite some con- 
vergence-still real differences in policies offered and implemented by parties. At its most basic, this mechanism implies that if there are more left leaning citizens, the chances for a left leaning party in government increases, which then, once elected, implements more left policies. This mechanism implies strong links between popular ideology, government ideology, and government policy, and the relevance of this hypothesis can be evaluating based on whether these links empirically exist.

\subsection{Individual Ideology and Government Policies}

Individual ideology may affect policy also by bypassing the electoral process. The median voter theory as stated by Downs would predict that policies pursued by both left and right governments converge towards the median (Downs, 1957). So, in the end, their policies may not differ that much, regardless of their ideological label. If the electorate shifts to the left, the median voter will shift too, and the parties, all parties!, will follow. The left party will be closing in to the median from the left side, the right party will be closing in from the right. If the median moves, so will the parties. If the electorate shifts to the left, one will observe a more left policy regardless of which party is in government. This is true for two-party systems, but also true for systems where proto-coalitions of parties, a left leaning block and a right leaning block, compete and in turn occupy the political offices. The proto-coalitions of parties, in particular parties not so extreme as to be mostly irrelevant, will converge towards the ideological center of gravity. Some empirical evidence for this convergence of policies is found already in the fact that differences in the economic policy among parties have diminished (Linhart \& Shikano, 2007; for Germany, Kim \& Fording, 1998 for a larger set of Western democracies). These findings indicate that there is less political will to enact an economic policy which is decidedly right or left. Empirical support for this mechanism would arise from a direct effect of popular ideology on policy, combined with the absence of an effect of government ideology on policy. An effect of popular ideology on government composition may exist, but it is not relevant for policies.

\subsection{General Trends, Common Challenges, and the Free Floating Political-Administrative System}

Up to now, the assumptions are that 1) elections matter for policy in that governments follow the ideology of the electorate, and 2) that there are differences in policies between left and right governments, as their campaign rhetoric would imply. However, one can question all of these assumptions on the basis of two arguments.

First, there might be general trends in policy making, which have their roots either in objective challenges (such as a major shift of employment in industrial production to employment in the service sector, the need for more qualified jobs, or demographics). Regardless of their ideology, governments have to tackle these challenges, and as the challenges are similar, policies addressing them are similar too. An electorate with a certain ideology votes a party with a corresponding ideology to power, but this does not matter for policies. If this argument is true, the link between popular ideology and government composition exists, but no link between a government's ideological composition and its policy. This should then be true for more or less all policies, as similar states are confronted with similar problems.

Second, one might recur to the public choice argument about preferences of governments as self-interested agent, which runs as follows: irrespective of its ideological creed, the political class and in particular the existing governmental bureaucracy below the politically elected level, per se will want to extent the scope of government, intensify regulation, enlarge the public sector and the amount of funds redistributed, as all of these are probate means to enlarge the public bureaucracy (Niskanen, 1971). From this argument it follows that one might observe a relationship between popular ideology and a government's ideological label, but no decisive link between a government's ideology and its policies. The effect of policy developments, which are isolated from popular ideology should be stronger for policies, where the political-administrative system has a stake, e.g. policies involving redistribution and the size of the public sector.

\section{Analysis and Results}

The empirical analysis will describe the development of popular ideology, test for its relevance for certain public policies, and compare the findings with predictions derived from the three mechanisms outlined in the above section. 


\subsection{Methods and Data}

A statistical analysis has to look for the effects of aggregated individual-level ideology on electoral outcomes and governmental policies, and this will be done by performing regression analyses of aggregate data at the national level. At this level, a case is constituted by one country in one year. The data structure of the macro-level data is a time series cross sectional data set, supplemented with information about the ideological self-placement obtained for countries in the Eurobarometer surveys. The number of countries is roughly equal to the number of periods, albeit unbalanced: for some countries, there are 22 points in time, for others only 4 . An exploration reveals that most of the variation occurs between the countries, a finding indicating that there are differences among countries, which are relatively stable over time, while all countries are subject to the same trends in many regards. We are interested in explaining the differences between the countries characterized by certain features, and we are interested differences which remain after controlling for existing trends. Given the data structure, we chose OLS with panel corrected standard errors, including an AR1 process of the error terms (Beck \& Katz, 1995). The correlation of the residuals $(t$ and $t-1)$ for most dependent variables, as obtained by an OLS regression is 0.80 .

As for the case selection, there clearly is a range of factors relevant for governmental policies apart from popular ideology. The question here is how to establish whether the ideology of citizens has a genuine effect on government composition and/or governmental policies, or not. This warrants a most similar system design, in which the cases selected for a comparison are most similar in as many regards as possible. For this reason, we chose EU member states, specifically the Eurobarometer data set which covers some 20 years and allows to track the development of citizens' economic ideology over a longer period for a set of countries which are relatively similar in many social and institutional aspects. Moreover, the ideological content of "Left" and "Right" is more homogeneous in the European culture (Kim \& Fording, 1998: p. 76; Benoit \& Laver, 2007; Klingemann et al., 2006).

The data required encompasses information on a country's popular ideology, government composition, and policies enacted. Data on popular ideology was obtained by aggregating individual-level survey data from the Eurobarometer surveys to determine the country's position on the left-right scale by computing the national average of individual self-placements for a given year. Higher values of the variable Left Scale indicate a more left-leaning population. The information on government composition captures which political bloc-left, center or right - was in control of government during a specified period, the data used is from the CPDS Dataset compiled by Armingeon et al. (2011). Data on policies is constrained by the availability of comparable data. The analysis uses data provided by the Quality of Government Project (Teorell et al., 2009). For the quantitative comparison required by this study, this implies a focus on policies which are usually labeled as "size of government”: Social Expenditure, the magnitude of redistribution via the welfare state, and Government Size, defined as the size of the public sector. Both policies are either intervening in the market place (by redistributing outcomes) or limiting the market place (by extending the public sector). The variables are measured as the share of GDP being redistributed by social and welfare spending, and the share of GDP going into wages and salaries paid by the government. Employment Protection is a third policy variable for which quantitative data is available, covering the degree of employment protection, as compiled by the OECD (2004).

All three policies have in common that they are strongly relating to the core of the left-right ideological dimension, and left and right imply different and moreover easily identifiable differences in the policies. For all three policies, the left's ideological program implies higher levels of the variables, i.e. one would expect positive and significant coefficients of Left Scale on each of the policies. The three policies differ in the degree to which they imply a growth of the government's bureaucracy and the available budget at disposition of the government. In both aspects, Employment Protection is, in Niskanian terms, less attractive for the political-administrative system.

\subsection{Ideology of Citizens and Parties}

When comparing the left-right positioning of citizens across countries and over time, the first caveat is whether there is a real change in ideology, or whether there is merely a shift in content of the labels. The ideological scale, which was asked in an identical manner for decades, should be calibrated. Calibrating the ideological scale has two aspects. First, what is "left" in a particular country, compared to "left" in another one? In some countries, the "left" might be quite moderate, in others, they might be quite socialist, while both call themselves 
"left". Thus, it is unclear whether "left" and "right" self-placements are comparable across countries, whether a score of 6 on a 1 to 10 scale in country A is indeed $10 \%$ more to the left than a 5 in country B. It is also questionable whether a "6" in country A leads to a policy which is also $10 \%$ to the left, e.g. $10 \%$ more interventionist compared with a policy resulting from a " 5 " in country B. This holds true even if the parties act as perfect transmission belts of popular ideology. The same is true over time: if the content of left and right changes over time in a country, it difficult to operationalize the effect of left ideology on policies: For instance, if a " 5 " on the scale stands for a liberal state-economy relationship in a society at one point in time, it might stand for much more influence of the government on the economy at another time.

The calibration of the ideological scale can be tackled using party positions from a comparative analysis of party manifests to "calibrate" the left-right scale for an international and longitudinal comparison-a comparison using the same set of criteria to locate a certain party in an identical ideological space, to reveal, whether a certain party moved in one direction on the ideological scale, and also, whether a party labeled "social democratic" in one country occupies the same position ideologically as a party with the same label in a different country. The study by Lowe et al. did exactly this, compiling a data set containing the positions of parties on several ideological and policy scales, as based on the content of their electoral platform and manifest. By design, the scores obtained are comparable over time and across countries, because the coding was done according to the identical standard (Lowe et al., 2011a; Lowe et al., 2011b). Thus, given the fixed standard by which the manifestos are coded, a shift to the left is really a shift to the left, not just a result of a change in the content and meaning of "left". The coding scheme defines a fixed ideological scale, on which positions can be located and movements can be discerned.

Regarding the question at hand, when keeping the meaning of "left" constant, as the comparative analysis does, the shift of the parties becomes obvious (cf. Figure 1).

Using the stance of parties toward the free market, with positive values indicating positive stance towards a free market and negative values indicating the a negative stance, Figure 1 illustrates that political parties underwent a secular change: they converged and they moved to the left position of less support for free market principles. Parties' evaluation of the free market is now much more homogeneous than earlier on, and the evaluation is also more negative than it used to be, i.e. the position of all parties in this issue moved to the left, towards less support for the free market mechanism. The trend towards less support for the free market among parties is also significant: regressing the party positions on time yields a significant negative coefficient. Equivalent results can be obtained for parties' positions towards labor policy or the state-economy relationship, here to the trend towards more left positions is significant. Given that parties track voter movements, this finding is

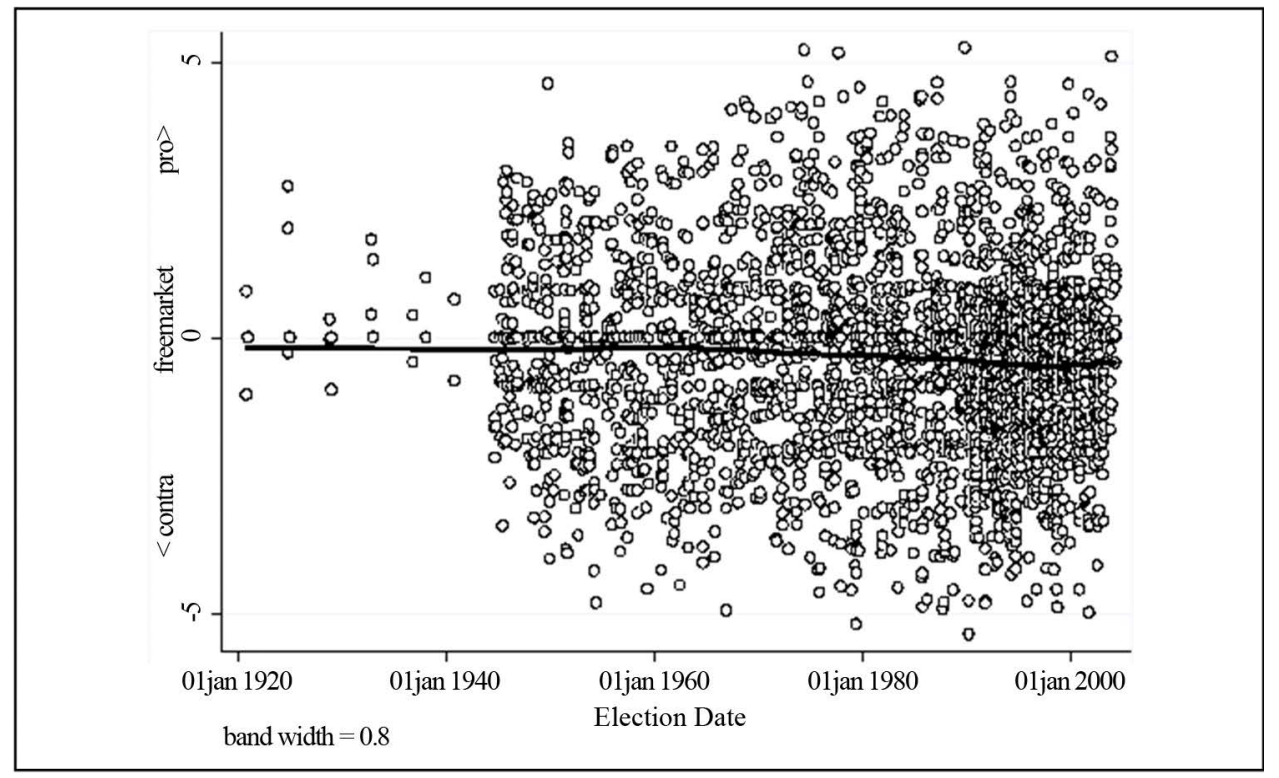

Figure 1. Development of party positions on the free market dimension. Remark: data from the manifesto project (Lowe et al., 2011b), bold line indicates the LOWES-smoother. 
supportive of the observation presented later on in more detail, viz. that voters and citizens also moved to the left.

What is the development of popular ideology? For those twelve European countries, for which we have a longer time series of data, Figure 2 gives the development of the national mean of citizen's self-positioning on the left-right-scale, Left Scale, where higher values indicate more left attitudes.

The most striking observation is that of an ideological convergence similar to the parties: while the countries were quite heterogeneous in the beginning of the survey period, the $70 \mathrm{~s}$, the country means are by the end of the $90 \mathrm{~s}$ more similar then they were ever before. However, this development is not constituting a symmetric funnel, centering on the middle of the scale. While not easily recognizable, the development of average ideology is also trended, and significantly so: per year, the national means move by 0.0175 points to the left. Indeed, much of the variation in the beginning of the period under consideration is due to Italy being significantly more left than the other countries in the sample. Italy is the only case which is persistently drifting to the right in that the mean of the Left-Right-scale moves to the right, which puts Italy's curve into the middle of the crowd. All other countries are moving to the left. Given the observation of a real shift in party positions, this shift in popular ideology is in all likelihood also a real ideological shift in absolute terms.

Not only is there a consistent shift in ideology towards the left, there is also the trend towards an increasing homogeneity of political opinions. The within-country political polarization, computed as the standard deviation of individual Left-Right-self-placements in the country in each year decreases, i.e. citizens are moving closer to the national average. Notably is also that the share of people with extremist political attitudes (defined as persons placing themselves in the two outermost categories of the Left-Right-Scale) declines also significantly over time.

Regarding the input to the policy-making process, the existence of a secular shift to the left among populations can be stated. Both, population and parties are drifting to the left. This shift is not an artifact, not a result of a changing meaning of what a "5" on the Left-Right scales implies in terms of political content and political demands. Even if the meaning is kept constant, the shift persists.

\subsection{Popular Ideology and Ideological Composition of Government}

The first link in the electoral mechanism is the link between popular ideology and government composition. Thus, the question is, does the shift of popular ideology express itself in that, for instance, a more left-leaning electorate votes left-governments into office?

On the one hand, one would presume that if citizens are leaning more to the left, the chances for a left party to

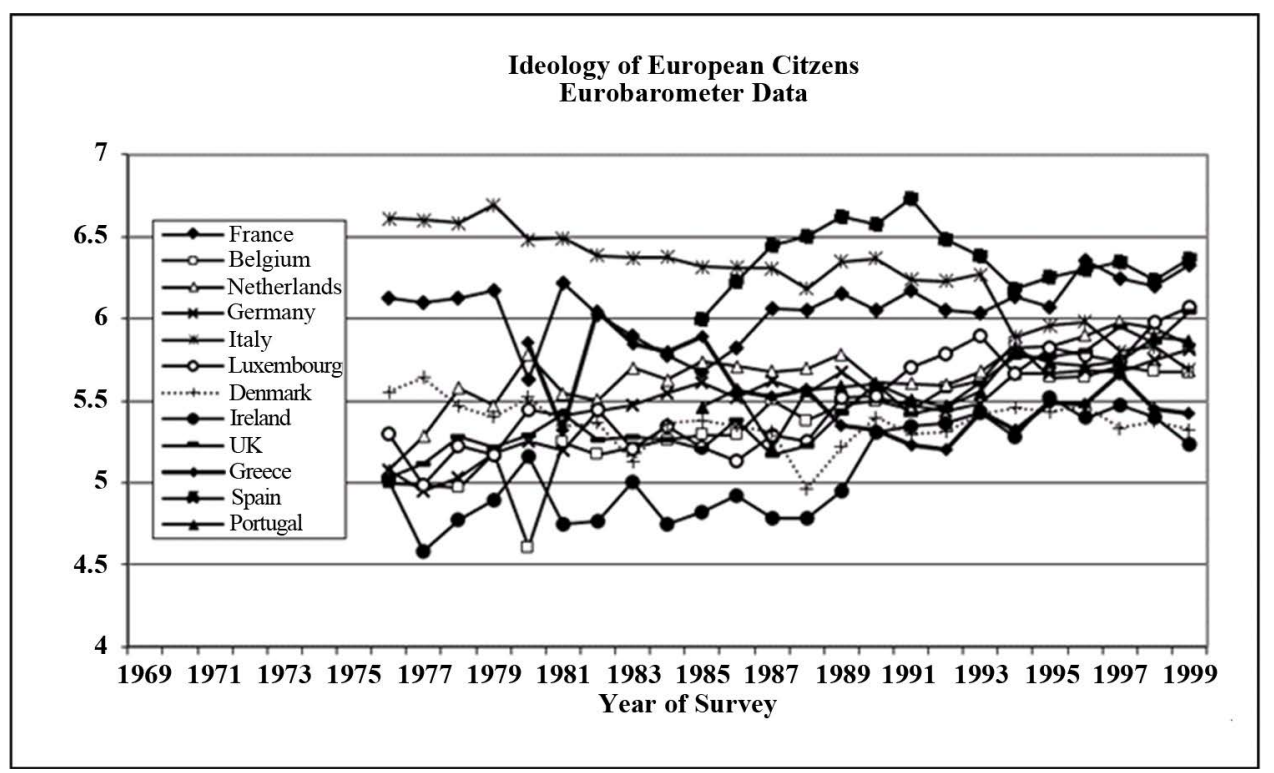

Figure 2. Popular ideology: left-right mean for all citizens of european countries over time. Remark: Own calculations based on Eurobarometer survey data, see Text. 
obtain government power are higher. On the other hand, the majority constraint and the vagaries of coalition building may cause a disconnect between ideological composition of the electorate and the ideological composition of the government. How are the empirical relationships?

Table 1 gives the result of a logistic regression which regressed the event "Left Party in Government" respectively the event of "Right Party in government" for the 86 elections in the period covered by the CPDS Data (Armingeon et al., 2011) on popular ideology and the recent economic growth in the country. The two leftmost columns in Table 1 give the results of regressing the share of votes for left parties on the two explanatory variables.

First, the results indicate that contrary to what one would expect, population ideology does not directly influence government ideology. While one would not, due to the majority constraint, expect a deterministic relationship, the insignificance of the effect of popular ideology on electoral outcomes is striking. A more left-leaning population does not lead significantly more often to a left party controlling the government, nor does a more leftist population vote in a way that results in significantly fewer right wing governments.

Second, when analyzing the share of votes going to left parties in parliament, where the majority constraint is not effective, the effect of the electorates' composition on the composition of parliament is both evident and significant: the more left the electorate, the higher the share of left parties in parliament.

Third, regarding the effect of the economic background of electoral outcomes, the finding indicates that the better the economic development was in recent times, the more likely is it that a right government is elected into office. For the share of left parties in parliament, the effect of the recent economic development is significantly negative.

As for the effect of ideology on public policy via the electoral route, i.e. via putting a government with a certain proclaimed ideology into office, this result is an important hint insofar as the very first link between popular ideology and public policy is non-deterministic: the ideological composition of the overall population does not affect political developments in a deterministic way. While explainable to electoral properties-electoral participation among voters from a certain end of the ideological spectrum, but also electoral rules-this finding raises a problem for studies which assume to capture the effects of popular ideology on social and economic developments, by using the ideology of the government as the indicator of the population's ideology (Bjornskov, 2005). It does not preclude that governments, irrespective of their ideological denomination, track popular ideology. Indeed, if the parties or proto-coalitions are converging, they are tracking the ideological center of gravity in the population. Thus for the following analyses, the effect of a more left leaning population is not synonymous (or, to put it more technical: not collinear) with the incumbency of left governments. If popular ideology shifts to the left, this does not mean that governments follow suit in terms of their explicit ideological label, but it can still imply that governments follow in their factual policies. If popular ideology moves to the left this may also mean that all parties, irrespective of their ideological label, react by offering more left-leaning policies and holding more leftist positions. As section 4.2 indicated, the comparison of popular ideology and party positions supports this argument. The following analysis will therefore include both, popular ideology and government ideology as explanatory factors.

\subsection{Popular Ideology and Public Policy}

Does popular ideology affect public policies? In particular, is there an effect of popular ideology which operates

Table 1. Popular ideology and government composition.

\begin{tabular}{|c|c|c|c|c|c|c|c|}
\hline & \multicolumn{2}{|c|}{ Left Government } & \multicolumn{2}{|c|}{ Right Government } & & \multicolumn{2}{|c|}{ Shares of Votes for Left Parties } \\
\hline & Model 1 & Model 2 & Model 3 & Model 4 & & Left Votes 1 & Left Votes 2 \\
\hline Left Scale T0 & 0.651 & 0.713 & -0.378 & -0.357 & & $4.929^{* * *}$ & $4.814^{* * *}$ \\
\hline Av 5Y GDP Growth Past & & -0.425 & & 0.266 & & & $-3.198^{* *}$ \\
\hline Constant & $-2.429^{* * *}$ & $-2.568^{* * *}$ & $-1.195^{* * *}$ & $-1.170^{* * *}$ & & $37.211^{* * *}$ & $36.774^{* * *}$ \\
\hline $\mathrm{N}$ & 86 & 86 & 86 & 86 & & 86 & 86 \\
\hline Pseudo $\mathrm{R}^{2}$ & 0.066 & 0.081 & 0.025 & 0.036 & R2 & 0.205 & 0.273 \\
\hline
\end{tabular}

Remark: Logit Model, explanatory variables are standardized, see Appendix. 
circumventing the loose electoral link from voters to governments and their policies?

The following analysis tests for effects of popular and government ideology on three policies which offer themselves for a quantitative analysis, Employment Protection, Social Expenditure, and Government Size. As for what could be expected, four situations can be outlined which relate to the mechanisms outlined in section 3: 1) if popular ideology is the driver of policy, a shift to the left should show up it a shift to the left in all three policies. 2) If governments with different ideological labels actually implement distinctive policies, the ideology of the incumbent government should also matter. 3) If all parties and coalitions track the median voter or popular ideology, only popular ideology should matter, but there should not be a difference in policies implemented by governments labeled left or right. 4) If neither popular nor government ideology matters, this would be indicative of either a free floating political system, or of a universalism in that all governments are confronted with the same societal problems and react in the same way.

The content of policies for which there are effects of popular ideology compared with policies, for which there are no such effects, may hint at the mechanism actually at work. While the three policies chosen for the analysis share the feature that a left-leaning population expresses demand for more of each (more welfare, more employment protection etc.), they differ regarding the question of whether the government per se has an interest in what direction these policies shall take, an interest based on the Niskanian argument about the size of the public bureaucracy. By setting policies about employment protection, the state sets the rules by which other actors have to live. Increasing regulation of the employment market may also call for a bigger role of public actors, notably the courts and monitoring institutions, but at its core employment protection it is about the relationship between employers and employees. The degree to which public bureaucracy can be inflated by regulating employment relationships is not comparable to the degree that the other two policies are able to increase the size and the power of the public bureaucracy. So, while regulating employment conditions might be a policy where left and right governments differ, the effect of the free floating political-administrative system pursuing its own agenda will express itself in the two other policies, and if this argument holds true, it will do so without differences between left and right governments.

Empirically, all three policies are correlated but explained to varying degrees by different factors; they all affect the relationship between the state and the economy, and are related to the factors we are interested in, economic development, popular ideology and government composition. Tables 2(a)-(c) give the results of an exploration into the political and ideological factors of policy content.

The effects found for the political variables are consistent, in that they are mainly independent of other control variables, such as GDP or time, which are of much higher relevance.

Regarding popular ideology, the findings indicate that it affects employment protection, but neither the size of the welfare state nor the size of government. The same is true for the share of voters for left parties, as an alternative measure of popular ideology.

Regarding the effect of government composition, a government's ideological orientation does not matter substantially for any of the three policies under consideration here. A government's ideology does neither matter for the state-economy-relationship, nor for the size of the welfare state, nor for the regulation of the legal relationships between the employees and the employers. There are substantial developments in each of these policies over the last decades, and, as these changes do not track popular ideology, it is by no means sure that these developments are in line with the preferences of voters as expressed by voting a certain party into office.

Contrary to employment protection, social expenditure and government size are strongly trended. Both are increasing constantly, but not due the observable ideological shift to the left in the population. As for other factors, societal wealth affects two policies: in the wealthier countries in the sample, the level of employment protections is lower and the size of the government is smaller. Referring to the distinction made above between the three policies, policy development tracks popular ideology only where the political-administrative system has no stake in a particular policy development. Developments of the two policies where the political-administrative system has an interest in a particular development (expanding the state bureaucracy and state budget), are isolated from popular ideology.

Coming back to the electoral chain linking popular ideology and policy, the second link is also very loose: governments of the left and the right do not differ in how they shape or try to shape these policies. This is not to say that this finding precludes differences between left and right governments in other issues, such as civil rights or environmental protection. But regarding some of the predominant issues underlying the ideological left-right-dimension, policies of ideologically different governments do not differ. 
Table 2. (a) Determinants of employment protection. (b) Determinants of social expenditure. (c) Determinants of size of the public sector

(a)

\begin{tabular}{|c|c|c|c|c|c|}
\hline & Model 1 & Model 2 & Model 3 & Model 4 & Model 5 \\
\hline Left Scale Lag 2 & $0.152^{* *}$ & & $0.149^{* *}$ & $0.169^{* *}$ & \\
\hline Left Share Votes & & $0.127^{* *}$ & & & $0.164^{* * * *}$ \\
\hline Left Government & & & 0.005 & 0.011 & -0.001 \\
\hline Right Government & & & -0.000 & -0.010 & 0.003 \\
\hline GDP & & & & $-0.406^{* * *}$ & $-0.281^{* * *}$ \\
\hline Year & & & & -0.015 & -0.082 \\
\hline $\mathrm{R}^{2}$ & 0.043 & 0.027 & 0.042 & 0.153 & 0.111 \\
\hline $\mathrm{N}$ & 206 & 315 & 206 & 206 & 315 \\
\hline $\mathrm{N}$ (Countries) & 15.000 & 15 & 15 & 15 & 15 \\
\hline
\end{tabular}

(b)

\begin{tabular}{|c|c|c|c|c|c|}
\hline & Model 1 & Model 2 & Model 3 & Model 4 & Model 5 \\
\hline Left Scale Lag 2 & 0.035 & & 0.030 & 0.022 & \\
\hline Left Share Votes & & -0.013 & & & -0.002 \\
\hline Left Government & & & 0.008 & 0.004 & -0.002 \\
\hline Right Government & & & -0.017 & -0.013 & $0.027^{*}$ \\
\hline GDP & & & & 0.088 & $-0.264^{*}$ \\
\hline Year & & & & $0.339^{*}$ & $0.618^{* * *}$ \\
\hline $\mathrm{R}^{2}$ & 0.005 & 0.000 & 0.009 & 0.091 & 0.108 \\
\hline $\mathrm{N}$ & 271 & 574 & 271 & 271 & 402 \\
\hline $\mathrm{N}$ (Countries) & 16 & 23 & 16 & 16 & 16 \\
\hline
\end{tabular}

(c)

\begin{tabular}{|c|c|c|c|c|c|}
\hline & Model 1 & Model 2 & Model 3 & Model 4 & Model 5 \\
\hline Left Scale Lag 2 & -0.011 & & -0.011 & 0.001 & \\
\hline Left Share Votes & & -0.012 & & & -0.013 \\
\hline Left Government & & & 0.002 & -0.002 & -0.006 \\
\hline Right Government & & & -0.007 & -0.004 & 0.005 \\
\hline GDP & & & & $-0.521^{* * *}$ & $-0.745^{* * *}$ \\
\hline Year & & & & 0.207 & $0.547^{* * *}$ \\
\hline $\mathrm{R}^{2}$ & 0.001 & 0.000 & 0.002 & 0.127 & 0.177 \\
\hline $\mathrm{N}$ & 298 & 556 & 298 & 298 & 544 \\
\hline $\mathrm{N}$ (Countries) & 16 & 16 & 16 & 16 & 16 \\
\hline
\end{tabular}

Remark: Results as obtained using STATA xtpcse routine. ${ }^{*} p<0.05 ;{ }^{* *} p<0.01 ;{ }^{* * *} p<0.001$. All variables are standardized, see Appendix. 


\section{Summary and Conclusion}

To summarize, we find little evidence of an impact of popular ideology on public policies. The baseline argument was that of a link between popular ideology on the input side and policies on the output side: either a population more often elects a party with its favored ideology into office, which then implements policies more in line with popular ideology. Alternatively, parties, irrespective of their ideological label, pursue policies more in line with popular ideology because each side is tracking popular ideology, and converging to the political center of gravity, albeit from different sides. From both views, different predictions about effects can be derived. Under the first, popular ideology should affect government composition, which then should matter for policies chosen. Under the second, policies should track popular ideology, but there should not be an effect of government ideology.

Looking at popular ideology, the input to the political process, and party positions, we find a secular trend towards more left positions, implying that parties are seemingly tracking the population and voters in shifting their positions as expressed in their manifestos, if not their ideological label. Moreover, there is today more ideological homogeneity and less polarization among both, parties and citizens than in the 1970s. Given this shift, which we treat as exogenous, we would expect corresponding policy shifts, also to the left. While there is a shift in policies in the countries in the sample, this shift is not explainable by looking at the ideological leaning and the development of ideology in the countries' populations. While there might be policies, where the link between broad ideology and specific policy is not that straightforward, all three policies under consideration here are closely related to the left-right ideology dimension, and thus one would expect a relationship with popular ideology. If popular ideology really matters for policy development, popular ideology indicators should significantly affect these policies.

The empirical findings can be summarized as follows:

1) The link between popular ideology and government composition is non-deterministic, so it is necessary to include both analyses of policy determinants. Popular ideology is most often not measured directly, by recurring to voter surveys, but via parties in government and their ideological position as judged analyzing party manifestos. The assumption that parties in government are a good indicator of popular ideology is thus questionable.

2) Neither popular ideology, constructed by averaging ideological self-placements at the individual level, nor shares for left parties in elections as an alternative indicator consistently affect policies.

3) There is no difference in policy between governments of different ideology. The last finding is in line with the argument that parties or proto-coalitions are converging. As was said above, the tracking works in that parties are also more left, in pursuit of a secular shift in popular ideology. But regarding their actual policy, there are no differences between left and right governments.

If governments were perfect agents, a shift in popular ideology would translate in policy, by either of the two mechanisms outlined. This is not the case. This leaves two explanations: either that all governments purse the same policies in response to the same problems, or that governments do not actually care about their principals' ideological demands. To decide, which explanation holds true, one must look at different policies, notably policies, where governments as agents have a self-interest as opposed to policies, where the government as agent has no stake. Comparing, which policies track popular ideology and which are independent of it, indicates that governments indeed follow popular ideology in policies, where they have no stake and no bureaucratic self-interest in certain policy developments, but pursue their own agenda, where they have one. Popular ideology (as proxied by popular ideology and the ideology of the voters) matters only in an issue, where the political-administrative system, has no interest, but regulates the relationship between two other, private, actors. But for the size of government and the magnitude of redistribution, both issues where the bureaucracy can extend its size and power by extending the role of the state, popular ideology does not matter. Whatever happens here is done by the government and its bureaucracy, but not as a reaction to demands of the population.

\section{References}

Adams, J., Clark, M., Ezrow, L., \& Glasgow, G. (2004). Understanding Change and Stability in Party Ideologies: Do Parties Respond to Public Opinion or to Past Election Results? British Journal of Political Science, 34, 589-610. http://dx.doi.org/10.1017/S0007123404000201

Armingeon, K., Weisstanner, D., Engler, S., Potolidis, P., Gerber, M., \& Leimgruber, P. (2011). Comparative Political Data Set 1960-2009. Institute of Political Science, University of Berne. 
Beck, N., \& Katz, J. N. (1995). What to Do (and Not to Do) with Time-Series Cross-Section Data. American Political Science Review, 89, 634-647. http://dx.doi.org/10.2307/2082979

Benoit, K., \& Laver, M. (2007). Estimating Party Policy Positions: Comparing Expert Surveys and Hand-Coded Content Analysis. Electoral Studies, 26, 90-107. http://dx.doi.org/10.1016/j.electstud.2006.04.008

Bjornskov, C. (2005). Does Political Ideology Affect Economic Growth? Public Choice, 123, 133-146. http://dx.doi.org/10.1007/s11127-005-0263-3

Blekesaune, M. (2007). Economic Conditions and Public Attitudes to Welfare Policies. European Sociological Review, 23, 393-403. http://dx.doi.org/10.1093/esr/jcm012

Blekesaune, M., \& Quadagno, J. (2003). Public Attitudes toward Welfare State Policies: A Comparative Analysis of 24 Nations. European Sociological Review, 19, 415-427. http://dx.doi.org/10.1093/esr/19.5.415

Brunner, E., Ross, S. L., \& Washington, E. (2011). Economics and Policy Preferences: Causal Evidence of the Impact of Economic Conditions on Support for Redistribution and Other Ballot Proposals. The Review of Economics and Statistics, 93, 888-906. http://dx.doi.org/10.1162/REST_a_00088

Budge, I., \& Farlie, D. (1983). Explaining and Predicting Elections: Issue Effects and Party Strategies in Twenty-three Democracies. London/Boston: Allen \& Unwin.

Busemeyer, M. R., Goerres, A., \& Weschle, S. (2009). Attitudes towards Redistributive Spending in an Era of Demographic Ageing: The Rival Pressures from Age and Income in 14 OECD Countries. Journal of European Social Policy, 19, 195-212. http://dx.doi.org/10.1177/0958928709104736

Campbell, A., Converse, P. E., Miller, W. E., \& Stokes, D. E. (1960). The American Voter. New York: Wiley.

Downs, A. (1957). An Economic Theory of Democracy. New York: Harper.

George, V. (1998). Political Ideology, Globalisation and Welfare Futures in Europe. Journal of Social Policy, 27, 17-36. http://journals.cambridge.org/article_S0047279497005205 http://dx.doi.org/10.1017/S0047279497005205

Hibbs Jr., D. A. (1977). Political Parties and Macroeconomic Policy. American Political Science Review, 71, 1467-1487. http://dx.doi.org/10.2307/1961490

Hinich, M. J., \& Munger, M. C. (1994). Ideology and the Theory of Political Choice. Ann Arbor, MI: University of Michigan Press.

Holm, J. D., \& Robinson, J. P. (1978). Ideological Identification and the American Voter. Public Opinion Quarterly, 42, 235-246. http://dx.doi.org/10.1086/268445

Imbeau, L. M., Petry, F., \& Lamari, M. (2001). Left-Right Party Ideology and Government Policies: A Meta-Analysis. European Journal of Political Research, 40, 1-29. http://dx.doi.org/10.1111/1475-6765.00587

Jacoby, W. G. (1994). Public Attitudes toward Government Spending. American Journal of Political Science, 38, $336-361$. http://dx.doi.org/10.2307/2111407

Jacoby, W. G. (2010). Policy Attitudes, Ideology and Voting Behavior in the 2008 Election. Electoral Studies, 29, 557-568. http://dx.doi.org/10.1016/j.electstud.2010.04.003

Jaeger, M. M. (2008). Does Left-Right Orientation Have a Causal Effect on Support for Redistribution? Causal Analysis with Cross-Sectional Data Using Instrumental Variables. International Journal of Public Opinion Research, 20, 363-373. http://dx.doi.org/10.1093/ijpor/edn030

Kau, J. B., \& Rubin, P. H. (2002). The Growth of Government: Sources and Limits. Public Choice, 113, 389-402. http://dx.doi.org/10.1023/A:1020884121375

Kim, H., \& Fording, R. C. (2001). Voter Ideology, the Economy, and the International Environment in Western Democracies, 1952-1989. Political Behavior, 23, 53-73. http://dx.doi.org/10.1023/A:1017669614814

Kim, H., \& Fording, R.C. (1998). Voter Ideology in Western Democracies, 1946-1989. European Journal of Political Research, 33, 73-97. http://dx.doi.org/10.1111/1475-6765.00376

Klingemann, H.-D., Andrea, V., Bara, J., Budge, I. et al. (2006). Mapping Policy Preferences II. Comparing 24 OECD and 24 CEE Countries, 1990-2003. Oxford: Oxford University Press.

Larsen, C. A. (2008). The Institutional Logic of Welfare Attitudes: How Welfare Regimes Influence Public Support. Comparative Political Studies, 41, 145-168. http://dx.doi.org/10.1177/0010414006295234

Lewis-Beck, M. S. (1985). Pocketbook Voting in U.S. National Election Studies: Fact or Artifact? American Journal of Political Science, 29, 348-356. http://dx.doi.org/10.2307/2111171

Lewis-Beck, M. S., \& Paldam, M. (2000). Economic Voting: An Introduction. Electoral Studies, 19, 113-121. http://dx.doi.org/10.1016/S0261-3794(99)00042-6 
Lewis-Beck, M. S., \& Stegmaier, M. (2000). Economic Determinants of Electoral Outcomes. Annual Review of Political Science, 3, 183-219. http://dx.doi.org/10.1146/annurev.polisci.3.1.183

Linhart, E., \& Shikano, S. (2007). Die Generierung von Parteipositionen aus vorverschlüsselten Wahlprogrammen für die Bundesrepublik Deutschland (1949-2002). Working Paper No. 98, Mannheim: Universität Mannheim Mannheimer Zentrum für Europäische Sozialforschung.

Listhaug, O., Macdonald, S. E., \& Rabinowitz, G. (1994). Ideology and Party Support in Comparative Perspective. European Journal of Political Research, 25, 111-149. http://dx.doi.org/10.1111/j.1475-6765.1994.tb00414.x

Lowe, W., Benoit, K., Mikhaylov, S., \& Laver, M. (2011a). Scaling Policy Preferences from Coded Political Texts. Legislative Studies Quarterly, 26, 123-155. http://dx.doi.org/10.1111/j.1939-9162.2010.00006.x

Lowe, W., Benoit, K., Mikhaylov, S., \& Laver, M. (2011b). Replication Data for: The Manifesto Project Data Extended to Include the Logit Scales and Standard Errors. 2011-06-07, Mikhaylov [Distributor] V3 [Version]. https://dataverse.harvard.edu/dataset.xhtml?persistentId=hdl:1902.1/17073\&studyListingIndex=0_5770dea2e7a7c2ac7d89 $\underline{38933 f 90}$

Maloney, J., \& Pickering, A. (2008). Ideology, Competence and Luck: What Determines General Election Results? Discussion Paper No. 08/607, Bristol: University of Bristol.

McDonald, M. D., Mendes, S. M., \& Budge, I. (2004). What Are Elections For? Conferring the Median Mandate. British Journal of Political Science, 34, 1-26. http://dx.doi.org/10.1017/S0007123403000322

Nadeau, R., Lewis-Beck, M. S., \& Belanger, E. (2013). Economics and Elections Revisited. Comparative Political Studies, 46, 551-573. http://dx.doi.org/10.1177/0010414012463877

Niskanen, W. A. (1971). Bureaucracy and Representative Government. Chicago, IL: Aldine Atherton.

OECD (2004). OECD Employment Outlook. Paris: OECD.

Pickering, A., \& Rockey, J. (2011). Ideology and the Growth of Government. The Review of Economics and Statistics, 93, 907-919. http://dx.doi.org/10.1162/REST_a_00101

Poole, K. T., \& Rosenthal, H. (1997). Congress: A Political-Economic History of Roll Call Voting. New York: Oxford University Press.

Potrafke, N. (2012). Political Cycles and Economic Performance in OECD Countries: Empirical Evidence from 1951-2006. Public Choice, 150, 155-179. http://dx.doi.org/10.1007/s11127-010-9695-5

Rabinowitz, G., \& Macdonald, S. E. (1989). A Directional Theory of Issue Voting. American Political Science Review, 83, 93-121. http://dx.doi.org/10.2307/1956436

Rattinger, H. (1991). Unemployment and Elections in West Germany. In H. Norpoth, M. S. Lewis-Beck, \& J.-D. Lafay (Eds.), Economics and Politics: The Calculus of Support (pp. 49-62). Ann Arbor, MI: University of Michigan Press.

Rudi, T. (2009). Einstellungen zu Werten, Ideologien und Sachfragen als Determinanten des Wahlverhaltens in Mittel- und Südosteuropa. In O. W. Gabriel, B. Weßels, \& J. W. Falter (Eds.), Wahlen und Wähler (pp. 606-627). Wiesbaden: VS Verlag für Sozialwissenschaften. http://dx.doi.org/10.1007/978-3-531-91666-8 25

Rudolph, T. J. (2009). Political Trust, Ideology, and Public Support for Tax Cuts. Public Opinion Quarterly, 73, $144-158$. http://dx.doi.org/10.1093/poq/nfp012

Rudolph, T. J., \& Evans, J. (2005). Political Trust, Ideology, and Public Support for Government Spending. American Journal of Political Science, 49, 660-671. http://dx.doi.org/10.1111/j.1540-5907.2005.00148.x

Swank, O. (1993). Popularity Functions Based on the Partisan Theory. Public Choice, 75, 339-356. http://dx.doi.org/10.1007/BF01053443

Teorell, J., Charron, N., Samanni, M., Holmberg, S., \& Rothstein, B. (2009). The Quality of Government Dataset (Version 17 June 2009). Gothenburg: University of Gothenburg: The Quality of Government.

Whitten, G. D., \& Palmer, H. D. (1999). Cross-National Analyses of Economic Voting. Electoral Studies, 18, 49-67. http://dx.doi.org/10.1016/S0261-3794(98)00043-2

Wright, G. C., Erikson, R. S., \& McIver, J. P. (1985). Measuring State Partisanship and Ideology with Survey Data. Journal of Politics, 47, 469-489. http://dx.doi.org/10.2307/2130892

Wright, G. C., Erikson, R. S., \& McIver, J. P. (1987). Public Opinion and Policy Liberalism in the American States. American Journal of Political Science, 31, 980-1001. http://dx.doi.org/10.2307/2111232 


\section{Appendix}

\section{a) Data sources}

Teorell, J., Charron, N., Samanni, M., Holmberg, S., \& Rothstein, B. (2009). The Quality of Government Dataset (Version 17, June 2009). University of Gothenburg: The Quality of Government Institute.

Armingeon, K., Weisstanner, D., Engler, S., Potolidis, P., Gerber, M., \& Leimgruber, P. (2011). Comparative Political Data Set 1960-2009, Institute of Political Science, University of Berne.

OECD (2004). OECD Employment Outlook 2004. Paris: OECD.

Lowe, W., Benoit, K., Mikhaylov, S., \& Laver, M. (2011). Replication Data for: The Manifesto Project Data Extended to Include the Logit Scales and Standard Errors. Slava Mikhaylov [Distributor] V3 [Version]. http://hdl.handle.net/1902.1/17073 http://dvn.iq.harvard.edu/dvn/dv/Mikhaylov/faces/study/StudyPage.xhtml?globalId=hdl:1902.1/17073 http://www.kenbenoit.net/cmp/scales/ [last accessed 13 April 2015].

\section{b) Variables}

Left Government: Executive Party is a Left Party? $(0=$ no, $1=$ yes $)$

Right Government: Executive Party is a Right Party? $(0=$ no, $1=$ yes $)$

Left Votes: \%— share of votes for left, left socialist and communist parties in parliamentary elections

Political Data from the CPDS Dataset; see Armingeon et al. (2011)

Left Scale T0: Popular Ideology—current mean of individual left right positionings (10 = Left)

Left Scale Lag 2: Popular Ideology—mean of individual left right positionings two years preceding $(10=$ Left)

Own calculations based on aggregated Eurobarometer data. The Eurobarometer trend file contains the question where on a left-right-scale individuals would place themselves, the individual values were aggregated for each country for each year, for details see text

Av 5Y GDP Growth Rate Past: Average GDP growth rate of the preceding five years

Social Expenditure (original label socexp_t): Total Social Expenditure (in \% of GDP)

Government Size (original label pwt_gsg): Government Share of GDP in \%

GDP (original label unna_gdpc): GDP per Capita

Economic data from Teorell et al. (2009)

Employment Protection: OECD indicator of Employment Protection (OECD, 2004) high values indicate a high level of employment protection 